pointment of his committees and thus actively assist in carrying out the policies that he proposed.

The Economic Entomologists will become more active and aggressive, if they fulfill their destiny and keep abreast of the progress of the modern world. They will broaden and strengthen their courses of instruction, insist on fundamentals and foundations in all branches. They will require longer and more adequate preparation for research and thus establish standards beyond reproach. They will welcome criticism, be generous in credit, seek coöperation; they will ally themselves with all forces that fight for the freedom of the earth from pest and disease. They will have faith to attempt the impossible and finally triumph, as do all forces that battle for truth and right.

At the close of the address a vote of thanks was extended by the association, after which the session adjourned.

Afternoon Session, Thursday, December $26,1918,2.40$ p. m.

President E. D. Ball: We will now take up the first paper on the program, by T. J. Headlee, New Brunswick, N. J.

\title{
PRACTICAL APPLICATION OF THE METHODS RECENTLY DISCOVERED FOR THE CONTROL OF THE SPRINKLING SEWAGE FILTER FLY
}

\section{(Psychoda alternata)}

By Thomas J. Hendlee, Ph. D., Entomologist of the New Jersey Agricultural Experiment Stations and State Entomologist

\section{INTRODUCTION}

Except where trade wastes are discharged in sufficient quantities materially to affect the effluent, sewage purification is essentially a process of transforming chemically unstable compounds into those which are chemically stable, and a process of reducing the number of pathogenic organisms to the lowest possible point, to the end that the water which has been used as a carrier for the sewage matters may be discharged into streams without polluting them in such a way as to be a menace to human health. The transformation of the chemically unstable sewage compounds to the chemically stable is apparently a bio-chemical process. The society of animals and plants effecting this change apparently reaches its highest development in the sprinkling sewage filter. The broken stones of which the body of this type of filter is composed are more or less completely coated with a gelatinous and amorphous film in which live the millions of organisms which effect this transformation. The organisms concerned are representatives at least of Bacteria, Fungi, Protozoa, Nematoda, Rotatoria, 


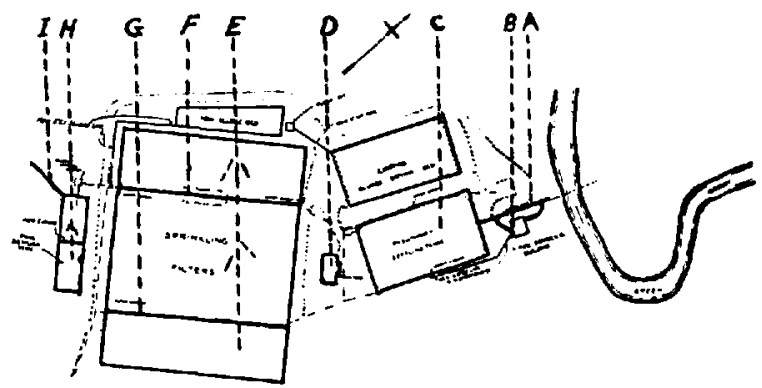

Fig. 1.-Diagram of the sewage purification plant where work against sprinkling sewage Filter Fly was carried out. Raw sewage enters at A, passes through B, C, $\mathrm{D}, \mathrm{E}$ and $\mathrm{H}$, and the purified effluent escapes through $\mathrm{I}$. The flies are produced in $\mathbf{E}$.

A-Stream of raw sewage; B-Screen for removing coarse matter; C-Preliminary settling tanks; D-Biphon dosing tanks; $\mathrm{E}$-Sprinkling filters; $\mathrm{F}$ and $\mathrm{G}-$ Galleries leading the sewage into and out of the sprinkling flters; H-Final settling tanks; I-Stream of effuent.

Chætopoda, Crustacea, Arachidna, and Insecta. The exact part which each group of organisms plays in the process of sewage purification is still an unsolved problem. The Psychoda are, however, con-

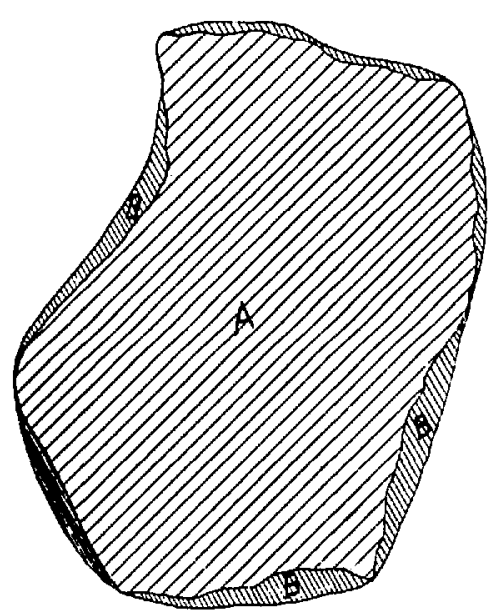

Fig. 2.-Diagram showing relation of film to stone. A, Stone; B, Film. cerned in the reducing of the gelatinous and amorphous film, living in it and consuming it. The principal species of Psychoda found doing this work at the Plainfield sprinkling sewage filter is $P$ sychoda alternata.

Nature and Extent of INJURY

So far as the present studies have gone there is nothing whatever to show that the Sprinkling Sewage Filter Fly in any way damages or interferes with the efficiency of the society to which it belongs. The adult flies, however, emerging in enormous numbers throughout the fore-part and throughout the latter part of the warm season, fly or are wind-carried for a distance of at least three-fourths of a mile, penetrate the finest screens and fall into the food which is presently to be consumed by people. Knowing the source of these flies and seeing them in the food, is sufficient to convince the people concerned that almost any infection from which they may subsequently suffer has been brought to them by this agency and to cause them to file suits for damage against the concern or the municipality maintaining the sewage

Plate 1. General view of the preliminary settling tanks (A), the sprinkling filter (B) and the final settling tanks (C). Sewage passes through in the order namod. The flies breed in the sprinkling filter. 


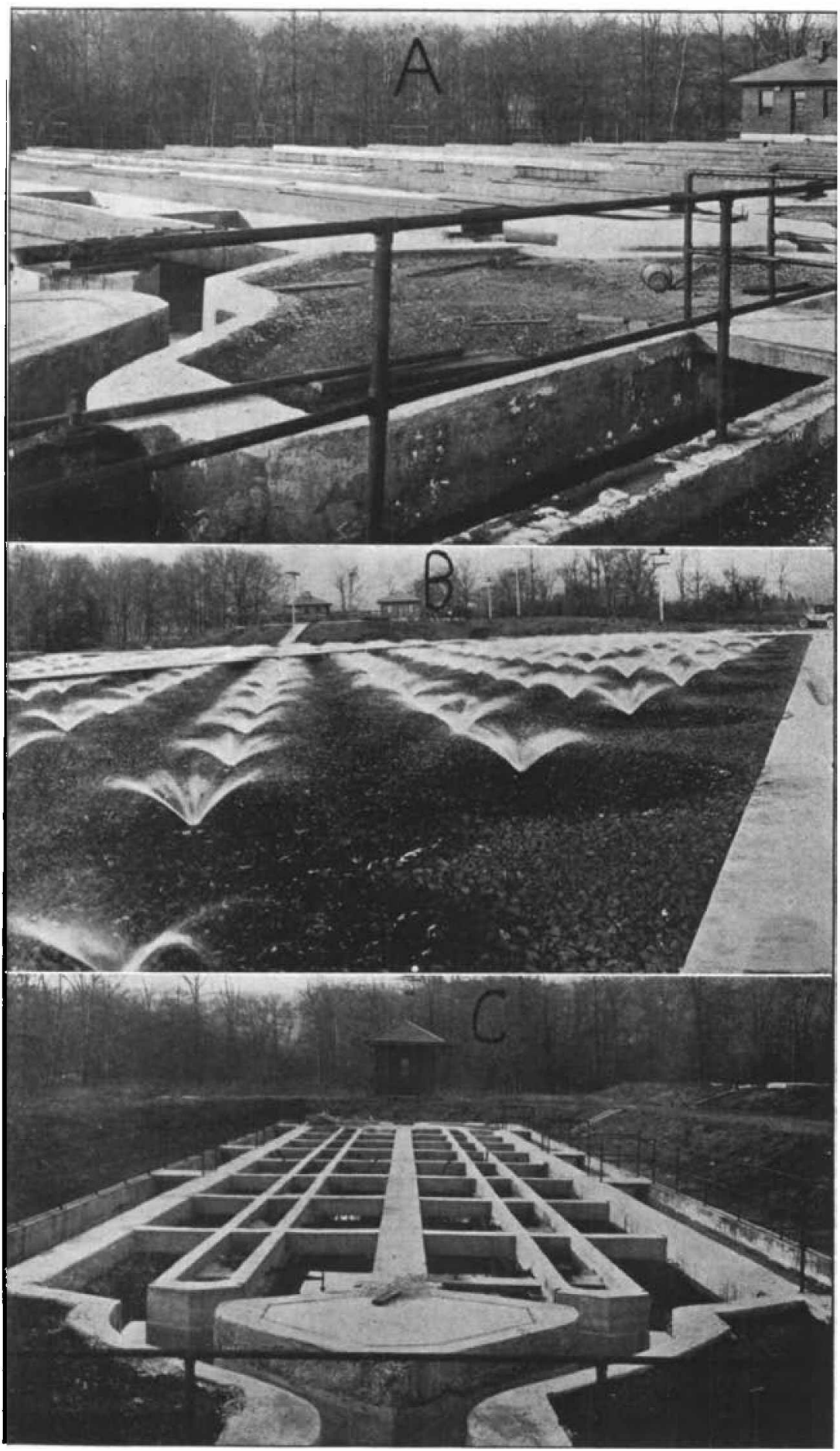

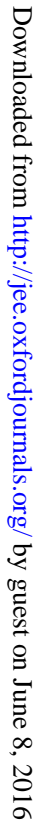


purification plant from which they come. Whether these fies actually carry infection has never been determined, but the presumption that they do is not at all unreasonable.

Almost wherever sprinkling sewage filters are maintained these flies are produced and trouble of this kind is likely to occur.
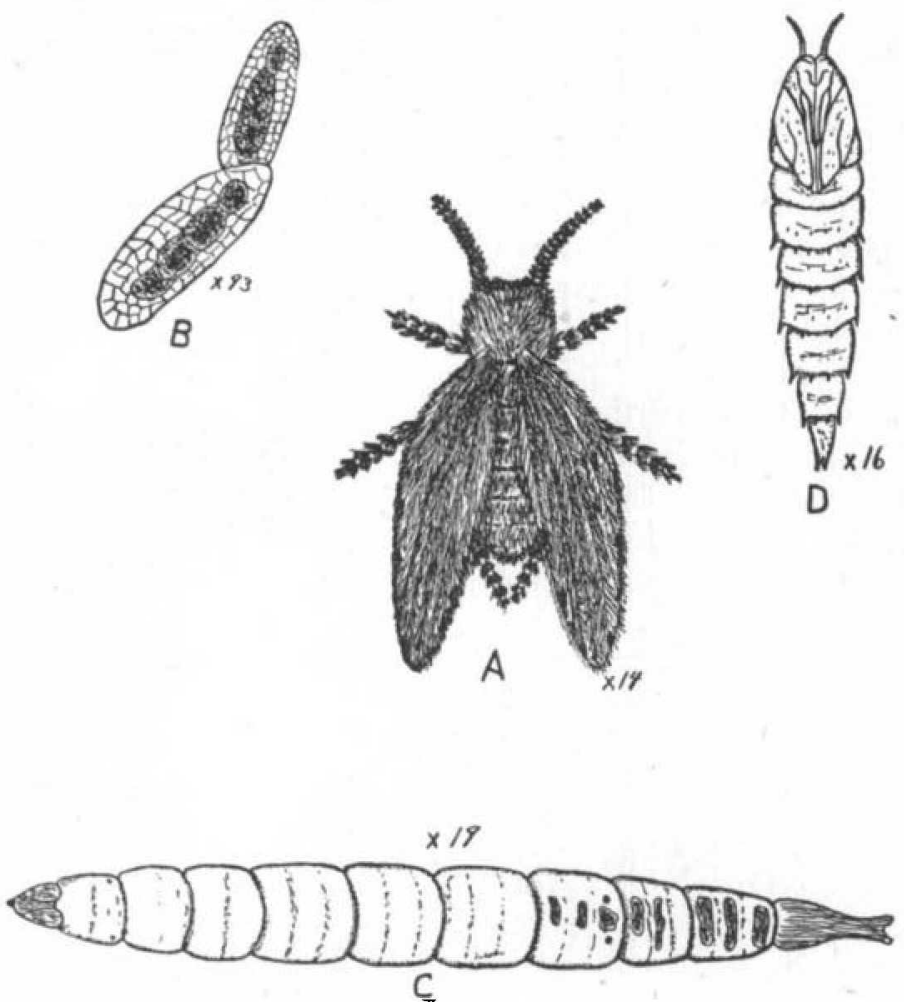

Fig. 3.-Life stages of the Sprinkling Sewage Filter Fly. A, Adult; B, Eggs (After L. Haseman); C, Larva; D, Pupa.

\section{Life-History and Habits}

The Sprinkling Sewage Filter Fly remains in the filter throughout the entire year, but to what extent breeding takes place in the winter time we are unable to say. Reproduction, however, occurred during the month of December, 1918.

The eggs are laid on the film. The young hatch and make their way into it. Here they establish themselves with the breathing tube projecting from the film surface and the body buried in it. In this position they feed and grow to maturity. Transformation to pupæ takes place in the film and the pupæ assume a position with their two breathing tubes sticking through the surface and the rest of their 
bodies buried in the film. When pupation has been completed the front end of the pupal shell is burst open and the fly emerges.

The insect is not a strong flier and its movements from the filter are much influenced by the wind. It has the habit of resting on the undersides of the stones in the upper layers of the filter and upon the sidewalls of the filter itself. The life cycle may be completed in the summer in a minimum of a little less than 12 days. As a matter of fact, a brood emerges during the summer about once each two weeks.

Although larvæ and pupæ of this fly may be found throughout the filter bed, they are most abundant in the zone which begins three inches below the surface and ends about twelve inches below the surface.

The abundance of larvæ and pupæ seems to be correlated with the thickness of the film. A thick film means heavy breeding, a thin film light breeding. During the winter and spring the film becomes very heavy and consequently the pest is very abundant, in the fore-part of the season. As the weather becomes warmer the filter unloads. Large quantities of the film sluff off and pass out with the effluent, and a thin film takes its place. This thin film gradually increases in thickness as the summer goes by, until in the latter part of the summer it becomes heavy and consequently develops a great abundance of flies.

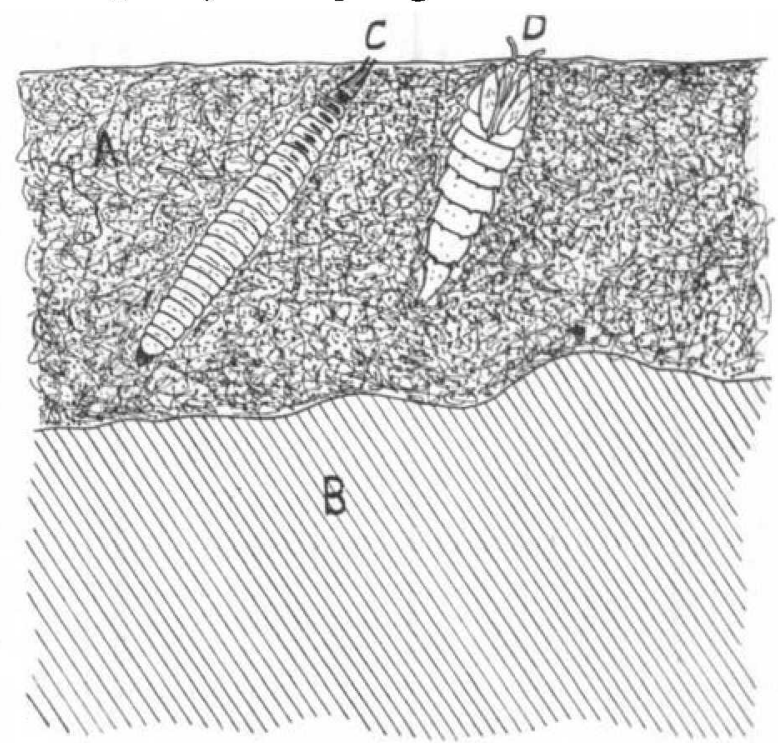

Fig. 4.-Diagram showing position of larva and pupa of the Sprinkling Sowage Filter Fly in the film. A, Film; B, Stone; C, Larva; D, Pupa.

\section{Control}

Practically all of the organisms composing the society of which the Sprinkling Sewage Filter Fly is a part, can get along without atmospheric oxygen for a longer time than it. Both the larvæ and pupæ 
breathe atmospheric air. Tests made and reported ${ }^{1}$ show that submersion of the filter bed with ordinary sewage for a period of 24 hours destroys 100 per cent of the larvæ and pupæ, leaving the film in active condition.

The first experimental submergence was made on June 14, 1918, and involved only one-fourth of the entire bed which has a surface of about two acres.

Acting upon this discovery, a bulk head pierced with a passage way which may be closed or opened at will was installed in each of the two galleries through which the effluent escaped from the filter bed of the joint sewage disposal plant of Plainfield, North Plainfield and Dunellen; a plant which serves to purify the sewage of about 40,000 people.

The factors affecting the submergence of the entire bed were tightness of the retaining walls, the volume of sewage available and the time which the bed could be submerged without injury. The retaining walls in question were composed of six-inch concrete backed by a heavy wall of soil lying at an easy angle of rest from the top of the retaining wall to the surface of the surrounding ground. This concrete wall had not been constructed to hold water, but merely to hold the stone in place and it surrounded a basin of approximately six feet deep. The normal volume of sewage ranged from $2 \frac{1}{2}$ to 4 million gallons daily. The time during which the filter could be submerged and not seriously injure the activity of the film as shown by the following table was something less than 48 hours.

Flooding Experiment Carried out in Flower Pots

Length of Time Flooded

16 hours
18 "
22 "
24
32 "
36 "
48 "

Condition of Larvæ

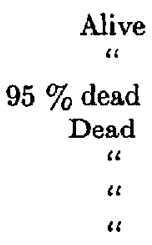

Condition of Film

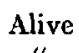

"6

if

it

16

Slight putrefication Putrefaction

The figures indicated that the filter should be filled with sewage, provided the walls did not leak seriously, within a period of 12 hours.

On August 9 the bulk head gates were shut and the water allowed to accumulate. The filter was completely under water at the end of 12 hours and was maintained in this condition for a period of 24 hours, when the bulk head gates were withdrawn and the waters allowed to escape. These escaping streams of water were full of the dead larvæ of the Sprinkling Sewage Filter Fly.

\footnotetext{
${ }^{1}$ Headlee, T. J., Beckwith, C. S. Sprinkling Sewage Filter Fly, Jounnal of Eсоломіс ENтомоцоGт, Vol. II, No. 5, 1918.
} 
Assuming that the nitration power of the bed is a proper index for its efficiency in sewage purification (this is the index usually so accepted by Sanitary Engineers), the following table will serve to show that the efficiency of the bed was in no wise diminished by the submergences of the season.

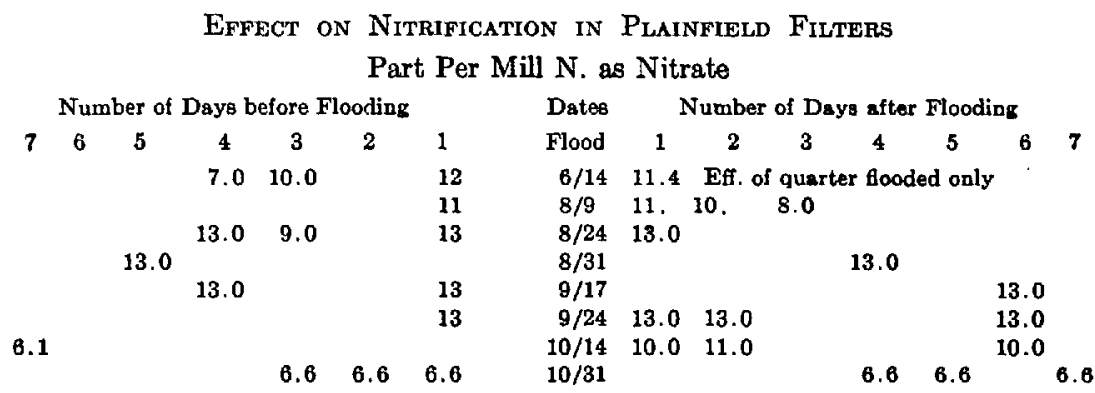

This submergence was repeated on August 24, August 31, September 17, September 24, October 14 and October 31.

With the exception of the periods from August 24 to August 31 and September 17 to September 24, the time elapsing was two weeks or greater. The result of the practice of allowing two weeks to elapse before the submergence is repeated appears in the escape of a considerable number of flies. A repetition of the treatment at the end of one week cuts the fly pest entirely out. The two-week period gives enough time for the flies to reach the adult stage and to reinfest the filter immediately after the water is withdrawn. Furthermore, it is possible although not actually determined that the egg is able to resist the submergence.

It is unmistakeably indicated that the filter should be submerged once each 10 days until the flies are reduced. Let it be understood, however, that at no time following August 24 did the fly assume the proportion of a pest, although the interval between submergence with two exceptions was sufficient for the insect to pass through its life cycle.

The work against the fly will be opened during the coming season by submergence of the bed in the spring before the flies emerge. This submergence will be followed by treatments at 10-day intervals until the fly has been so reduced as not to require such frequency.

The greatest limiting factor in the application of this method of controling the Sprinkling Sewage Filter Fy to the various sprinkling sewage filter beds of the country is the fact that many engineers have constructed these beds without retaining walls. In such cases the writer would recommend the construction of wooden walls backed by an earthen fill or the construction of concrete retaining walls, in such a

Plate 2. General views of sprinkling filter illustrating submergence. A.-Filter inactive, note apparatus for closing and opening the bulkhead gate; B-filter approaching complete submergence, sprayers discharging; $\mathrm{C}-$ Filter completely submerged. 


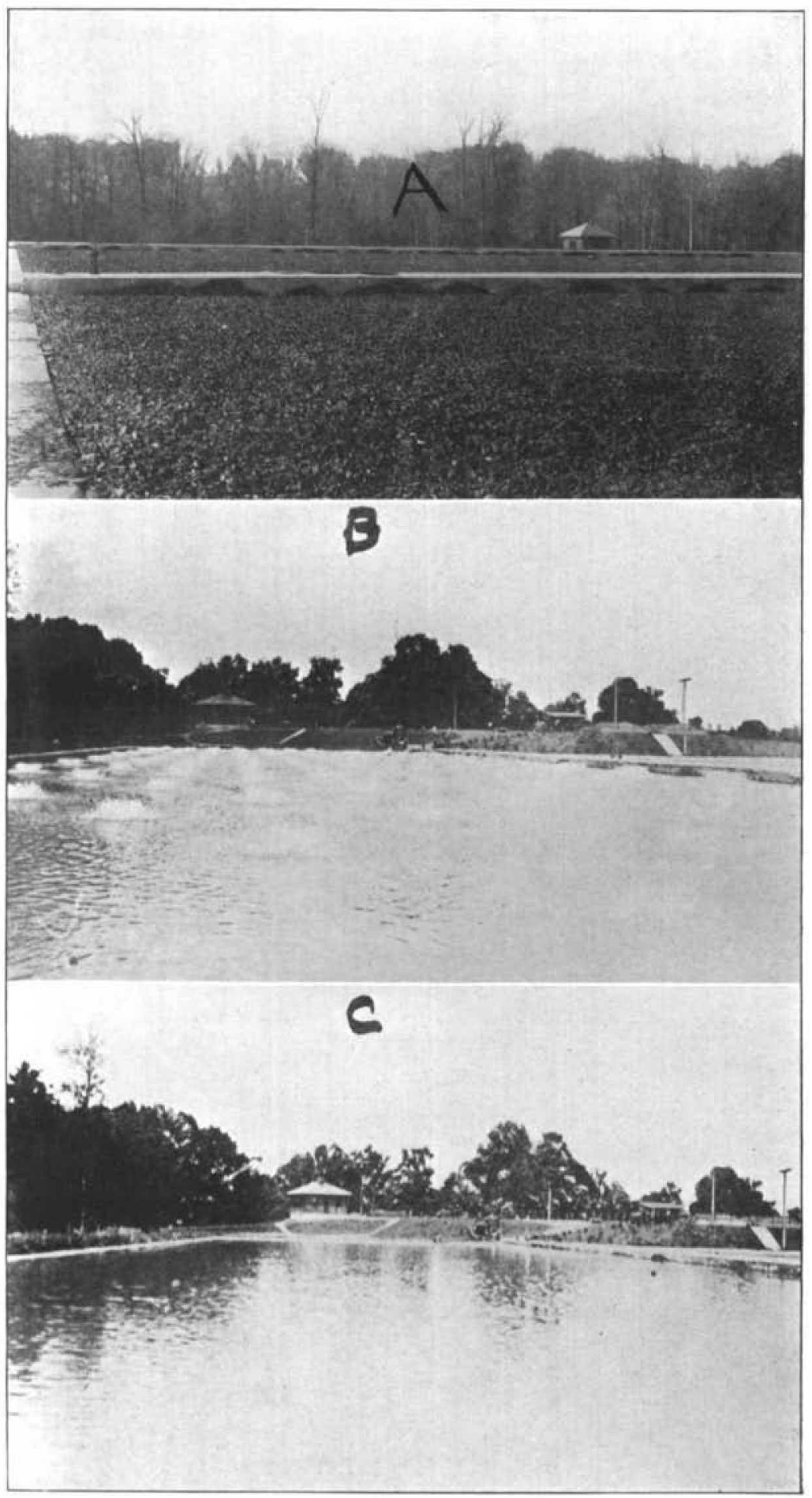


fashion as to permit the filling of the bed in 12 hours and the maintenance of the submergence for a period of 24 hours.

The writer wishes to take this opportunity to acknowledge his indebtedness to Dr. Leonard Haseman for identification of species, to the Joint Sewer Committee of Plainfield, Dunellen and North Plainfield for substantial aid in carrying out the experiments, to Mr. John R. Downes, superintendent of the disposal plant, for hearty coöperation in the practical work of submergence and for furnishing data on nitration, and to Mr. J. W. Thompson for making the drawings.

President E. D. Ball: This paper is before you for discussion.

Mr. W. A. RILEY: I had the pleasure of seeing some of this work last spring and was very much interested in the fact that while it had not been established definitely that those flies were carriers of disease, we have every reason to suppose that they would be under such circumstances, and I sympathize heartily with the people who brought suit against the corporation for maintaining such a nuisance. I think that Dr. Headlee's work will be very far reaching in its applicability. For one thing, a little later I saw the filter beds and the system in use here in Baltimore, or near this city. The beds of course are enormously more extensive and the pest was just as serious here. There have been a number of suits brought against the city and decided adversely to the city here, and this certainly should be a matter of much interest to the authorities in charge of that work.

Another factor which impressed me especially in the beds here was the number of other species of flies, including the house-fly, and a number of the larger Muscids breeding in these beds. I did not see that to any such extent at the beds in New Jersey, and that was very apparent when I visited the sewer beds here. The problem for this particular locality would make a very valuable and interesting one for some one who has local opportunities to take it up.

President E. D. Ball: Is there any further discussion? If not, we will call for the next paper.

\section{THE OCCURRENCE OF DROSOPHILA LARVE AND PUPARIA IN BOTTLED MILK}

By W. A. Riley, St. Paul, Minn.

(Withdrawn for publication elsewhere)

President E. D. Ball: The next paper on the program is, "Some Practical Phases of the Entomology of Disease, Hygiene, and Sanitation Developed by the War," by W. Dwight Pierce, Washington, D.C. 